\title{
Self Recorded Video and Diary Wrtiting Practices as a Way to Improve Higher Education Students' English Speaking Skills
}

\author{
Nita H. Koesoemah \\ Department of English, Politeknik Negeri Bandung \\ Bandung, Indonesia \\ E-mail: nita.henita@polban.ac.id
}

\begin{abstract}
Writing and Speaking are the productive Skills of a language. Although higher education students have learned English for years in primary and secondary schools, many of them do not find it easy to speak English in their college years while they will need English during and after they graduate. To improve their English, especially speaking skills, self video recording and diary writing practice was were carried out. This study was to analyze the effect of Self Recorded Video and Diary Writing on the improvement of English speaking skills of higher education students. The focus of this research is on four speaking skill categories; Pronunciation, Vocabulary, Grammar, and Fluency. to get the answer error analysis is used, and the result is presented using descriptive method. The data are students' self-recorded videos and diary writing was carried out once a week in one semester. The result obtained is that self-recorded Video, and diary writing can improve student speaking skills, especially in fluency, pronunciation, and vocabulary.
\end{abstract}

Keywords: fluency, self-recorded Video, diary writing, error analysis, descriptive method.

\section{INTRODUCTION}

Having learned English for more than six years in their primary and secondary schools, many higher education students still have a problem in their English, one of them is speaking. Considering the competitive condition in getting a job after the students graduate, it is our, as lecturers, job to prepare them the best we can. Patil (2008) said that it is the job of the lecturer to increase the students' -self-confidence by giving them tasks that can make them feel comfortable in using the language.

The ability to speak English is needed since many big companies, both national and international ones, perform their interviews in English as Zaremba (2006) claimed that in company recruitments, communication skill is considered more important than the experience, motivation, or academic achievement. Along with the idea, Gillis (2013) and Raine (2011) agreed that having a good ability of spoken English can support them in their career. Raine (2011) further stated that the word fluency covers the four necessary language skills; those are Speaking, Listening, Reading, and Writing, but fluency is closer to speaking skill. 
The practice is one of the keys to improving speaking skills. The word speaking practice is often associated with the involvement of some people, at least two. When the students who do not have enough self-confidence have to practice their English with other persons, they will feel uncomfortable as Hughes (2010) stated that speaking is different from writing that in speaking, we do not compose and edit what we are going to utter. He furthermore said that speaking is risky because we cannot edit what we have produced. When we edit it, what we have produced stay, to solve the problem, the students can practice by themselves.

The benefit of self-practice is the student can practice speaking by him/herself. Video recording can be used as a medium as it can enrich learning practice in the era of technology. McNulty and Lazarevic(2012) state that the use of the technology of Video can support second language learning. It is the media to do self reflect, analyze language problems, and lecturers can identify students' learning improvement. The video recording can be done anytime and anywhere, and according to Robertson (2009), to improve English, the students have to practice three times a week. In the process, along with lots of practice, the students speaking ability, their -self-confidence improved so that they do not feel hesitantly to talk in English to other people, at least about the topics they learn.

Speaking and writing belong to productive language skills, so both are closely related, as Meyers (2005) believed that writing is a way to produce language naturally achieved when someone speaks. Along with this idea, Jordan (1997) was convinced that in learning a second language, it is emphasized that all the language skills should be worked on simultaneously, and focusing on one skill should not interrupt learning the other skills. Even though Hinkel (2013) stated that acquiring an appropriate level of linguistic bases is crucial for developing writing skill to enable students to overcome a range of lexical and grammatical skills needed for writing progression, Silva (1990) believed that writing generally pursues a standardized form of grammar, structure, and vocabulary which cannot be separated from the structure of spoken sentences. As a result, writing practice not only exaggerates students' alert notification of the sentence structures while speaking but promote their speaking proficiency. Zhu (2007) demonstrated that high proficiency students write and speak better than common language proficiency ones. So when the students write specific topics related to the subject of English in the diary, then they will have something to talk about proficiently. 
As an English lecturer in the first semester, the writer provided the students with speaking and writing practices that could increase their speaking ability. This practice, self video recording, and diary writing were given as a weekly assignment. The practices were carried out mostly individually outside the classroom activities but about the same topics that were the topics of the semester. They had English subjects once a week, so the practices that should be performed at least was once a week. In the process, along with lots of practice, the 'students' self-confidence improved so that they did not feel hesitant to talk in English to other people, at least about the topics they learned and with their friends.

Previous studies have been conducted that examined the improvement of higher education students' speaking ability through self video recording, and another study was to see the effect of diary writing on the improvement of the students writing skills. This present study focus on the improvement of speaking ability through self video recording and diary writing. The result of the present study can inspire English lecturers to make their students practice speaking and writing independently that can be done outside the classroom in their own time, but should still be under the control of the lecturers by making the video recording and the diary writing as the assignment throughout the semester. Regarding the current relationship, this study tried to examine the effect of writing and speaking practice on speaking improvement of high education students through self video recording and diary writing. The questions were whether self video recording and diary writing could improve students' speaking ability and what most significant category (pronunciation, vocabulary, grammar, or fluency) improved.

\section{LITERATURE FRAMEWORK}

\section{Fluency}

The word fluency refers to language ability that covers the four primary languae skills, listening, speaking, reading, and writing, but fluency is most related to speaking Reine (2011). This word is related to the word self-confidence since lack of fluency is caused by a lack of -self-confidence of a person to talk in front of others. According to Bailey (2005), this problem can be resolved by using the right syllabus, teaching method, teaching materials, and assignment. One of the learning processes is independent study. 


\section{Independent Study}

According to Cady (1991), itis a process, method, and education philosophy in which learners acquire the knowledge on their own will. She further stated that independent study could also mean learning autonomy. Cited from Barilliaro (2011), Holec (1981) defines learning autonomy as the ability to be responsible for learning independently. When learners make many mistakes, they would feel embarrassed that could hamper their learning process, so the lecturer should be able to make the learners use the language comfortably.

\section{Self Video Recording}

In the era of technology, we could get moving images (Video) from various media, including the internet. Cellphones can be used to get and produce those pictures. Almost all lectures and students have cellphones that can be used in the teaching-learning process to improve students speaking fluency.

One of the assignments that can support independent study is expressing what they have in their thoughts and record them using their cellphones. Pitler (2007) believes the use of technology in the classroom can help learners to study independently, but Kearny and Schuck (2006) point out that independent study through self video recording needs learners' strong will and initiative. Kirkgoz (2011) said that learners speaking ability could improve significantly through self video recording. Along with the above statement, Carrera (2017) mentioned that giving the learners a task to do the self video recording for ten weeks improves motivation and learners' academic achievement. In the ten months, learners also improve their self-confidence moreover, Ching Sun \& FangYang (2013) and Ahn\& lee (2016) believed that learners' pronunciation also improves.

\section{Diary Writing}

Writing practice can be used to improve learners' writing ability. In his writing, Lagan's (2000) mentioned that writing practice is essential since writing is a skill, and the more we practice, the better our writing ability will be. Diary writing or daily journal writing is an excellent way to practice writing. To Hopkins (2010), one of the best ways of diary writing is that this activity allows learners to conduct it in many ways. 
HampandHeasley(2006) stated that through diary writing, learners obtain the opportunity to practice free writing anytime and anywhere. The writer might have the opportunity to explore experience or thing that they might feel more comfortable to put this into writing that discusses it with others. Fulwiler (1982) believes that writing something personal can help the writers when they intend to produce other types of writing; diary writing has a role as a brainstorming process to recover ideas for elaborating writing tasks. According to Spanventa (2000, p.168) "Diary writing helps writers develop creativity".

\section{The relation among writing and speaking}

Among the discrepancies between writing and speaking, both are productive skills, and they have many similarities and are much interdependent (Jordan, 1997). According to MacArthur, Graham, \&Fitzgerald (2008), the standard crucial cognitive potencies among writing and oral language makes the two primarily related to each other. Moreover, Zhu (2007) revealed that there is appositive connection among college-level ESL students' speaking and writing proficiency. The result demonstrated that high skilled students had both superior writing and speaking potency than the low proficient ones.

\section{METHOD}

This study was conducted in the first semester in which the subject given was BahasaInggris 1, with the focus was on speaking. The topics were general topics used in daily conversation, such as describing the object and giving directions. the students into the subjects by relating the contens of the topics to their major. For example, in informatics engineering, the content in the topic of describing an object was describing RAM or ROM.

This study was to explore the implementation qualitatively and the result of the students' self recorded Video and the diary writing in the self-learning process to improve the students speaking skills. The class had an English subject once a week, two hours in one session. To improve their English, the students needed more time to practice without taking an English course, but by practicing English actively with their friends, They were suggested to try to use English outside the class in their breaktime. This practice could be done if the students had enough self-confidence and did not afraid of making mistakes. 
Unfortunately, only some had this quality. In this case, self-recorded Video is an excellent way to practice speaking English and to make them even prepared to speak; they were also assigned to write diaries related to the topics, so that they would have got the subjects to talk.

From the beginning of the semester, the lecturer asked every student to write a diary and record a video at least once a week. In the Video, the students talked about various topics the students learned, such as introducing themselves, giving direction, and the topics on informatics engineering. These tasks were given to make them practice English by themselves and make them able to speak English. Their diary writing and self video recordings were counted as their additional scores to motivate them. The videos were taken using the students' phones and collected in C.D.s along with their diaries.

The lecturer, as the researcher, took three students' videos and diaries to be analyzed. The three students' videos and diaries were chosen from a higher, medium, and low achiever student. This was done to make the data used represent all students in the clas. The data was thenanalysed in the rubric so that the result can be pictured out. The schema of the research is as follows:

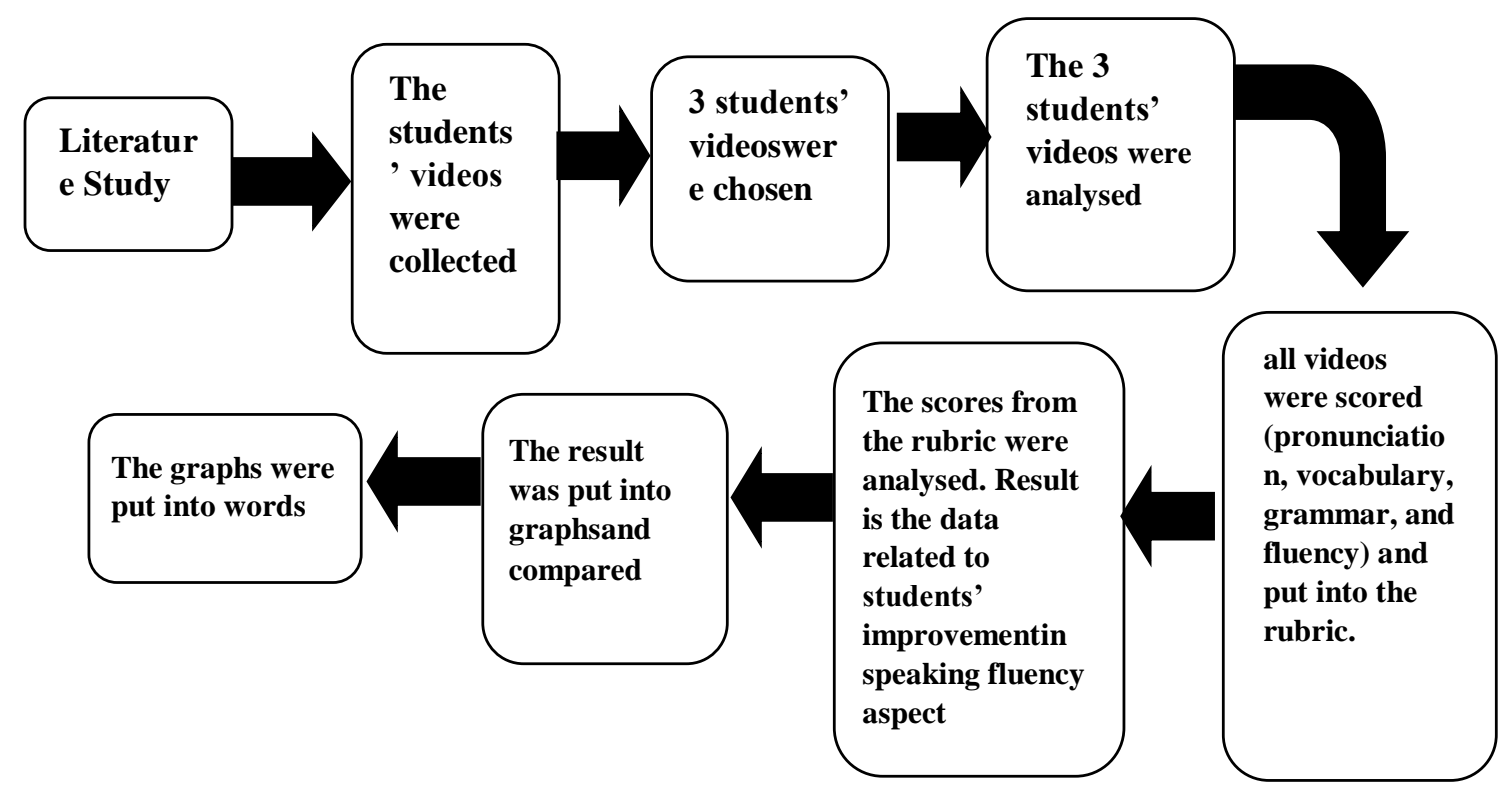

Figure 1. The schema of the research

The data was processed based on Verner's rubric in How to Evaluate Speaking. Verner (2017) stated that the lecturer could evaluate students speaking skills through a rubric, a table consisting of category columns in even numbers (the easiest is four 
columns). The first column is the category (Pronunciation, Vocabulary, Grammar, and Fluency). The other four columns are the score Scales (Need Improvement, Fair, Good, and Very Good). Those columns show the students speaking skills in each level. From the scores, we canidentify students' level. The rubric is as below:

Tabel 1 The scores rubric

\begin{tabular}{|c|c|c|c|c|}
\hline The category & $\begin{array}{l}\text { Need Improvement } \\
\text { (1 point) }\end{array}$ & $\begin{array}{l}\text { Fair } \\
(2 \\
\text { points })\end{array}$ & $\begin{array}{l}\text { Good } \\
\text { (3 points) }\end{array}$ & $\begin{array}{l}\text { Very Good } \\
\text { (4 points) }\end{array}$ \\
\hline Pronunciation & $\begin{array}{l}\text { Hard to understand, } \\
\text { too much silent, } \\
\text { unclear pronunciation }\end{array}$ & $\begin{array}{l}\text { Sometimes } \\
\text { unclear, but } \\
\text { generally good. }\end{array}$ & $\begin{array}{l}\text { Good } \\
\text { pronunciation, do } \\
\text { not disturb the } \\
\text { clarity of the } \\
\text { words. }\end{array}$ & articulated words \\
\hline Vocabulary & $\begin{array}{l}\text { Lack of Vocabulary to } \\
\text { express ideas, lots of } \\
\text { pauses to think }\end{array}$ & $\begin{array}{l}\text { Able to use } \\
\text { production } \\
\text { vocabulary to } \\
\text { some extent but } \\
\text { still repeating the } \\
\text { same words and } \\
\text { cannot talk more } \\
\text { about ideas. }\end{array}$ & $\begin{array}{l}\text { Use specific } \\
\text { vocabulary } \\
\text { instructed in the } \\
\text { semester. Use } \\
\text { vocabulary } \\
\text { appropriate to the } \\
\text { contexts in which } \\
\text { they are speaking. } \\
\text { Level of } \\
\text { vocabulary Able } \\
\text { to produce a good } \\
\text { level of } \\
\text { vocabulary } \\
\text { without prompting } \\
\text { they are } \\
\text { performing in this } \\
\text { area. }\end{array}$ & $\begin{array}{l}\text { Wide variety of } \\
\text { vocabulary, } \\
\text { accurate, } \\
\text { impressive use of } \\
\text { vocabulary, use } \\
\text { the vocabulary } \\
\text { learned inside and } \\
\text { outside class. }\end{array}$ \\
\hline Grammar & $\begin{array}{l}\text { Have difficulties in } \\
\text { expressing ideas } \\
\text { caused by } \\
\text { grammatical errors }\end{array}$ & $\begin{array}{l}\text { Able to express } \\
\text { ideas but with } \\
\text { inconsistent } \\
\text { structure and } \\
\text { tenses. }\end{array}$ & $\begin{array}{l}\text { Able to express } \\
\text { ideas well but } \\
\text { often make an } \\
\text { error in the tenses, } \\
\text { able to correct } \\
\text { them, though }\end{array}$ & $\begin{array}{l}\text { Able to express } \\
\text { ideas easily } \\
\text { in good structure } \\
\text { and tenses. }\end{array}$ \\
\hline Fluency & $\begin{array}{l}\text { Very slow speech, } \\
\text { nervous and unsure. } \\
\text { Short expressions. } \\
\text { Hard for listeners to } \\
\text { understand. }\end{array}$ & $\begin{array}{l}\text { Slow speech and } \\
\text { often unsure. } \\
\text { Some sentences } \\
\text { are not complete } \\
\text { but able to } \\
\text { continue talking. }\end{array}$ & $\begin{array}{l}\text { Able to produce a } \\
\text { speech that is } \\
\text { almost perfect but } \\
\text { sometimes there is } \\
\text { a kind of } \\
\text { hesitation and do } \\
\text { not run smoothly. } \\
\text { This may be } \\
\text { caused by } \\
\text { changing or trying } \\
\text { to find the words. }\end{array}$ & $\begin{array}{l}\text { Almost all the } \\
\text { speech is like or } \\
\text { close to a native } \\
\text { speaker. }\end{array}$ \\
\hline
\end{tabular}

The diaries or journals were used to build students' confidence in speaking. Students usually feel uncomfortable when they are given writing tasks since they feel that 
their writings containing a lot of mistakes and errors will be corrected by their lecturer Hedge (1991). Moreover, HampdanHeasley (2006) believed that some people write spontaneously and feel excited to know that other people read their writings, but not by their lecturers. When the people who are going to read their writing are their lecturers, they become reluctant to do so. For these reasons, the lecturer acted as the researcher, did not involve too much in their writings. The lecturer controlled the students writing by pair checking (in two or three-week time). The checking was more on the contents and to make sure that all the students made their weekly assignments.

\section{RESULTS AND DISCUSSION}

The result of the eleven videos student 1(a high achiever) in points can be seen below:

\begin{tabular}{|c|c|c|c|c|c|c|c|c|c|c|c|}
\hline Video & 1 & 2 & 3 & 4 & 5 & 6 & 7 & 8 & 9 & 10 & 11 \\
\hline points & 13 & 13 & 14 & 14 & 14 & 15 & 15 & 15 & 15 & 15 & 15 \\
\hline
\end{tabular}

We can see that the points are going bigger after two and three videos.

The result of the 11 videos of student 2 (a low achiever) in points:

\begin{tabular}{|c|c|c|c|c|c|c|c|c|c|c|c|}
\hline Video & 1 & 2 & 3 & 4 & 5 & 6 & 7 & 8 & 9 & 10 & 11 \\
\hline points & 9 & 9 & 9 & 9 & 9 & 10 & 10 & 10 & 10 & 10 & 10 \\
\hline
\end{tabular}

Although student 2 did not make a great improvement, but still the last six videos are better than the first five.

The result of the 11 videos of student 3 (a mid achiever) in points:

\begin{tabular}{|c|c|c|c|c|c|c|c|c|c|c|c|}
\hline Video & 1 & 2 & 3 & 4 & 5 & 6 & 7 & 8 & 9 & 10 & 11 \\
\hline points & 9 & 9 & 9 & 9 & 10 & 10 & 11 & 11 & 11 & 11 & 11 \\
\hline
\end{tabular}

Student 3 videos shows that the first four videos stay in one point (9) but then on the fifth, there is an increase, finally on the seventh until the last Video, the point are bigger that the previous one.

The result of the three students' videos can be seen in the graph below: 


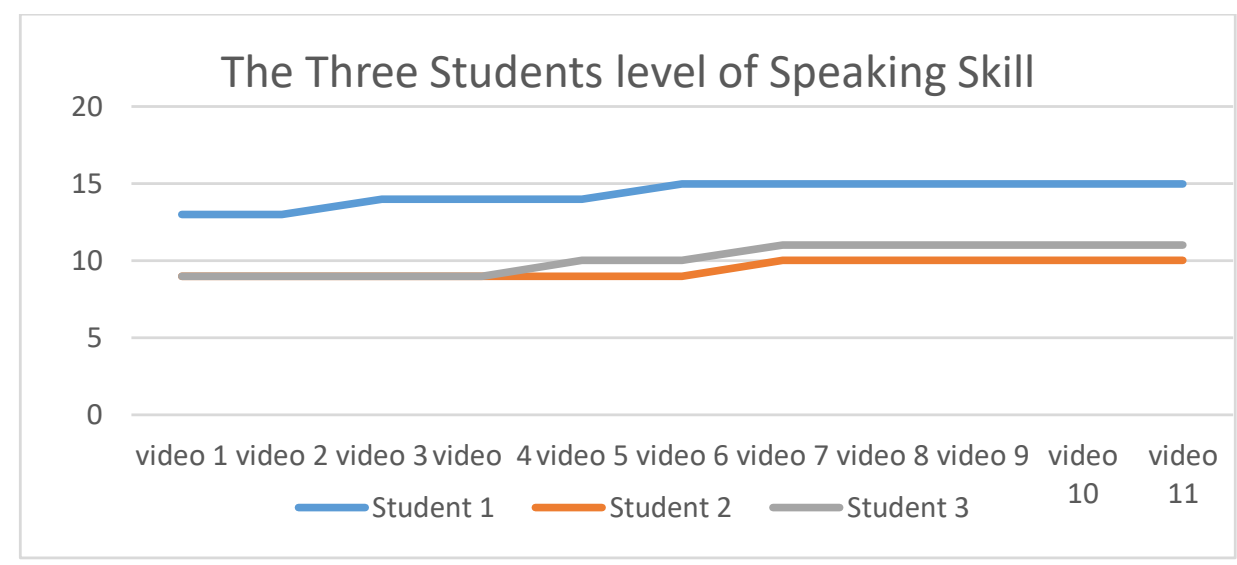

Graph 1. The student's level of speaking

From the graph, we can see that there's an improvement in all of the three students although the points are not the same. Student 1 started to gain the improvement in video 3 and keep increasing. Student 1 position is above of those of student 1 and 2 .

Compared to the research conducted in 2017, the Improvement of Student Speaking Skills through Self Video Recording (without diary writing assignment), we learned that using this method there was still improvement in their speaking ability, although there was flunctiation from the start until the last Video.

The improvement of each student language can be seen below:

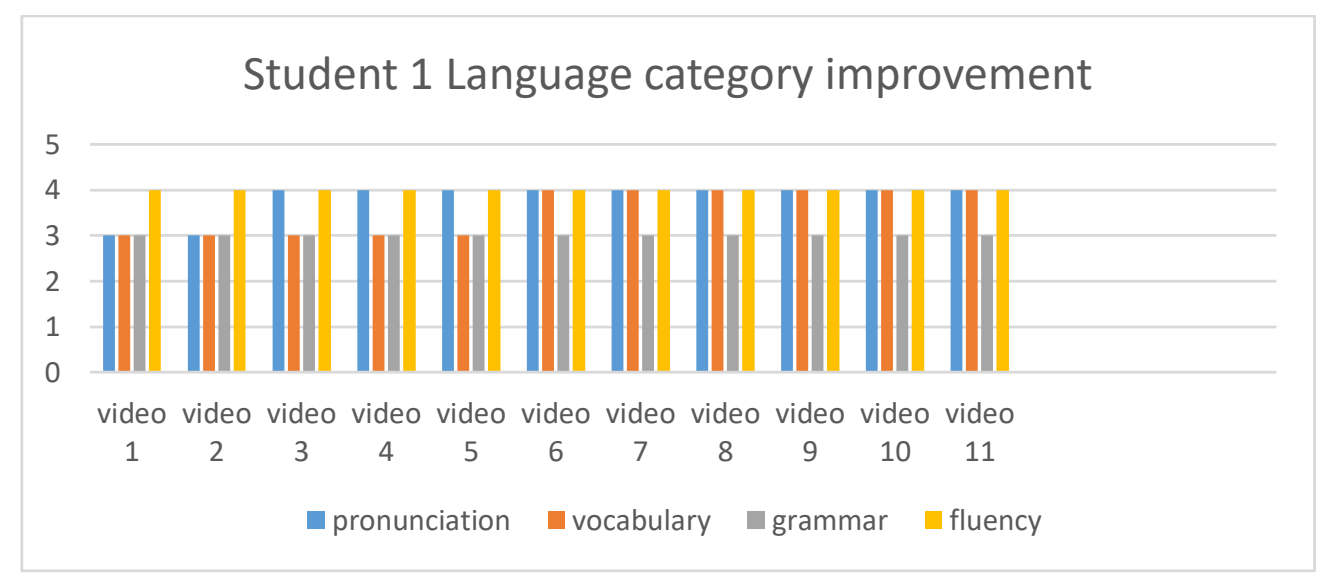

Graph 2. Student 1 language category improvement

Graph 2 shows that even from the first two videos, student 1 did not have a problem in fluency, but pronunciation, vocabulary, and grammar were not as good as fluency. In each language category. From the third Video until the last, the pronunciation 
was good. Then in the Video six, student 1 has improved his/her vocabulary. This stayed until the last Video. Unfortunately, it did not happen to grammar. It stayed stagnant from the first until the last videos. So we can conclude that self video recording could improve students' speaking ability, and diary writing supports students' fluency since they have the content to be expressed orally in the Video. The most significant category (pronunciation, vocabulary, grammar, or fluency) improved, were fluency and pronunciation.

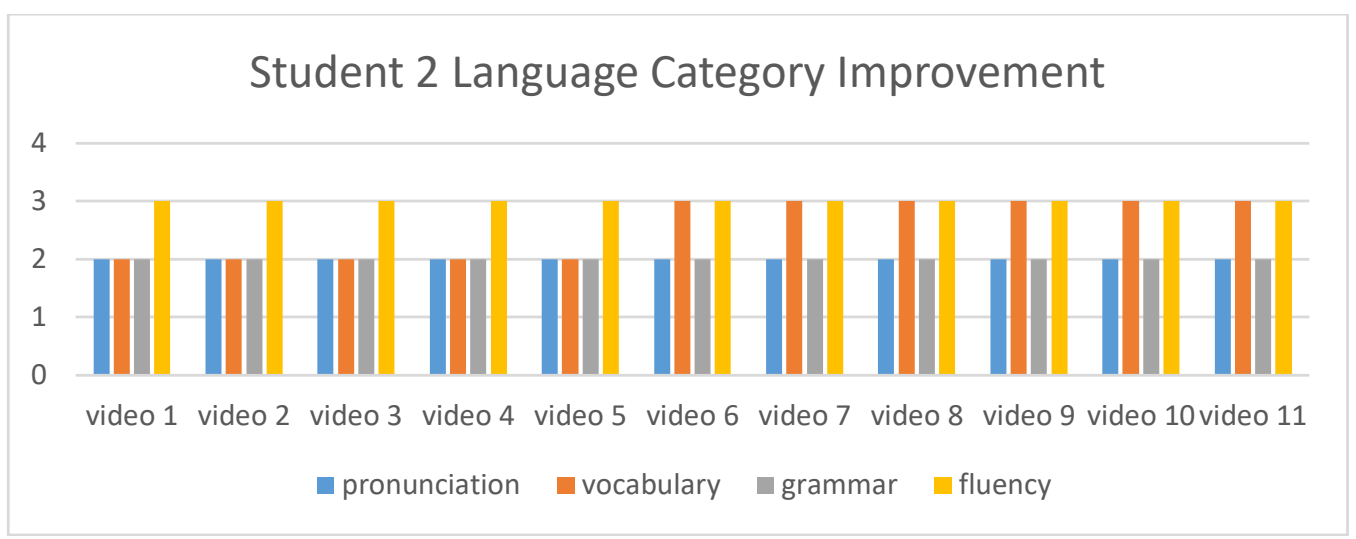

Graph 3. Student 2 language category improvement

From graph 3 we can see that in the first five videos, student 2 pronunciations, vocabulary, and grammar were in the same position in the 2 points. The fluency category in all the videos was the same in 3 points. Then from the Video six to the eleventh videos, the vocabulary went into point 3 along with pronunciation. It stayed in that position until the last Video.

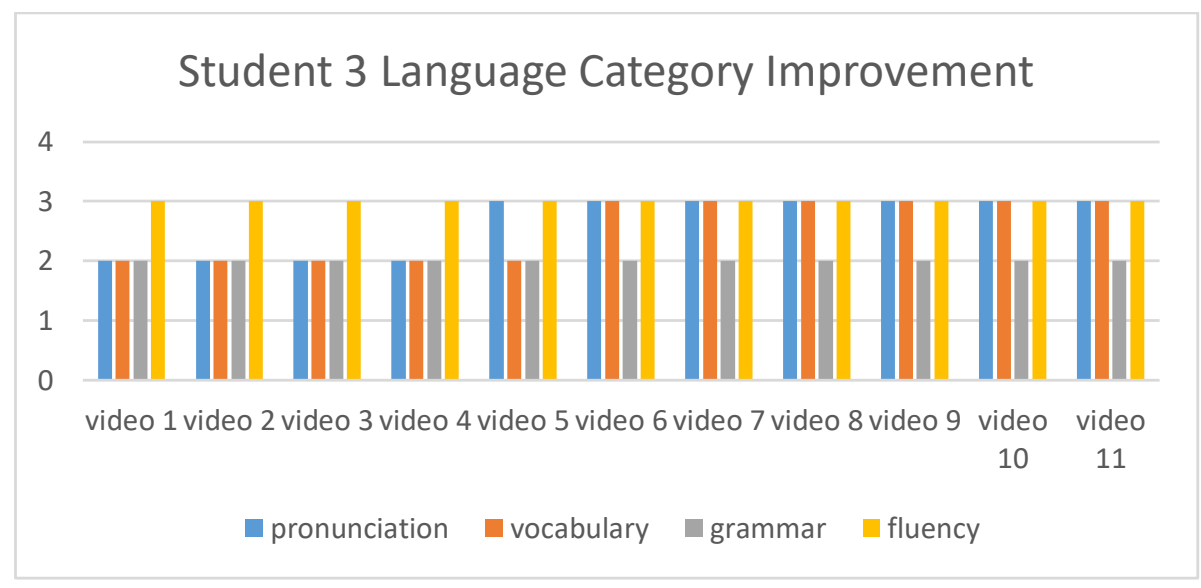

Graph 4. Student 3 language category improvement 
Graph 4 shows that in the first four videos, the category of fluency was in the position above of those three other categories, which were in point 2 but then in Video five, the position of vocabulary went in to point 3. From Video six to Video eleven, the fluency category went up to 3 points joining pronunciation and vocabulary. Grammar stayed the same as in the initial position.

The result of this study shows that all of the students improved in their speaking ability. A high achiever was in the higher position of the improvement from the two others. From a mid-achiever started improving his/her speaking ability earlier that the low achiever but later after the high achiever. No matter the points they got but all of the three students were managed to improve in their speaking skills, but the grammar was considered difficult, all of the three students did not improve.

Grammar might be improved through journal/diary writing, but since this research focused on speaking skill, the ability to speak, to make them have their self-confidence, the diary writing assignment were meant to prepare them to have topics to talk about. Grammar was discussed in general.

\section{CONCLUSION}

To conclude, students got more confidence in speaking fluency. All of the students could speak fluently from the start, followed by vocabulary (in the case of low achiever) and the mid achiever and high achiever. Their improvements were almost all categories but not grammar.

Besides fluency, vocabulary was also significantly improved. This is due to whatKirkgouz (2009) agreed that by writing a diary, many students are exposed to learning and remembering the meaning of unfamiliar words. It means that writing a diary helps students to remember the meaning of unfamiliar words that they use because they will be familiar with new words in expressing their feelings in a diary.

It is understood that although writing and speaking are two separated skills, they both belong to the productive skills of language and they share. Some identical elements, these two skills are associated to each other but with various ways of production (Cleland\& Pickering, 2006; Oxford, 1990). 


\section{REFERENCES}

Ahn, T. \& Lee, S. (2016). The user experience of a mobile speaking application with automatic speech recognition for EFL learning. British Journal of Educational Technology 47.4, 778-786

Barillaro, F. (2011). Teacher perspectives of learner autonomy in language learning. $M A$ dissertation, TESOL Centre, Sheffield, Hallam University.

Candy, P. (1991) Self-direction for lifelong learning: a comprehensive guide to theory and practice. San Francisco: Jossey Bass.

Carrera, D. (2017). How Does Explaining Content Through Videos Benefit Language Learners? Esp Students Tell About It. Turkish Online Journal of Education Technology. Special Issue for IETC 2017. 385-391

Cleland, A. A., \& Pickering, M. J. (2006). Do writing and speaking employ the same syntactic representations? Journal of Memory and Language, 54(2),185-198.

Fulwiler, T. (1982). Journal writing and its benefits in an upperintermediate EFL class. Columbia: Universidad Nacional deColombia

Gillis. G ( 2013) in Communicationscommunication skills, effective communication, Gerald Gillis, importance of speaking skills, public speaking, speaker, speaking skills cited from http://www.geraldgillis.com/importance-speaking-skills/

Kirkgoz, Y. (2009). Proceedings of the 10th METU ELT Convention: Exploring growth in vocabulary learning through learner diaries. Retrieved on December 19, 2016, from http://dbe.metu.edu.tr/convention/proceedingsweb/Growth.pdf

Kirkgoz, Y. (2011). A Blended Learning Study. An Implementation Video Recorded Speaking Tasks in Task based Classroom Instruction. Turkish Online Journal of Education Technology. 104. 1-13

Hinkel, E. (2013). Teaching academic ESL writing: Practical techniques in vocabulary and grammar (2nded.). NewYork, NY: Routledge.

Hughes, R. (2010). Materials to develop the speaking skills, in N. Narwood (Ed.). English language taching materials: theory and practice. Cambridge: Cambridge University Press. 
Jordan, R. R. (1997). English for academic purposes: A guide and resource book for teachers. Cambridge: CambridgeUniversityPress.

Kearney, M., and Schuck, S. (2006). Spotlight on authentic learning: Student developed digital video projects. Australasian Journal of Educational Technology 2006, 22(2), pp. 189-208.

MacArthur, C.A., Graham, S., \& Fitzgerald, J. (Eds.), (2008). Handbook of writing research. NewYork, NY: GuilfordPress.

Meyers, A. (2005). Gate ways to academic writing: Effective sentences, paragraphs, and essays. London, UK: Longman.

Patil, Z.N. (2008). Rethinking the objectives of teaching English in Asia. Asian EFL Journal.10 (4), 227-240. Retrieved from http://www.asian-efljournal.com/December_08_zn.php

Pitler, H., Hubbel, E., R., Kuhn, M., and Malenoski, K. (2007). Using technology with classroom instruction that works. Colorado: McREL.

Raine, P (2011). Promoting speaking fluency. Cited fromTEFL Jouney, October 8, 2011

Robertson, K. (2009) dikutipdarihttp://www.readingrockets.org/article/five-thingsteachers-can-do-improve-learning-ells-new-year

Silva, T. (1990). Second language composition instruction: Development, issues, and directions in ESL.In B. Kroll (Ed.), Second language writing: Research insights for the classroom (pp.11-23). NewYork, NY: CambridgeUniversityPress.'

Verner, S. (2017) cited fromhttp://busyteacher.org/4836-how-to-evaluate-speaking.html

Yu-Chih Sun \& Fang-Ying Yang. (2013). I help therefore, I learn; service learning on Web 2.0 in an EFL speaking class, Computer Assisted Language Learning 28.3, 202-219

Zaremba, A. J. (2006). Speaking professionally. Canada: Thompson South-Western.

Zhu, X.-h. (2007). What do we know about the relationship between speaking and writing in college-level ESL students? US- ChinaForeignLanguage,5(3),31-40. 